\title{
PENYULUHAN PENGELOLAAN PROGRAM DAN \\ IMPLEMENTASI LEMBAGA DAKWAH MAJELIS TA'LIM \\ IHYA AS-SUNNAH DI KECAMATAN SUKAJADI KOTA \\ BANDUNG JAWA BARAT
}

\author{
Nierna Yayah Daryanti \\ Kementrian Agama Kota Bandung Jawa Barat \\ neirnayayahdaryati@gmail.com \\ Hemlan Elhany \\ Institut Agama Islam Negeri Metro \\ Hemlanelhany69@gmail.com
}

\begin{abstract}
The results of the study of the management in majlis ta'lim as a place to shape one's character and from education itself become a reference for sukajadi people in practicing every teaching that has been given. In the management of the majlis ta'lim Ihya As-Sunnah, it has only reached the stages of design, organizing activities, given guidance, and also supervision. Then in organizing the activities it has not been carried out as optimally as possible, because in an organizational activity there must be community participation, not to stop in the middle of the road. The motivation carried out by the assembly is only an input, or an appeal to the managers and also the congregation. Sometimes the controls that are exercised by the majlis have not been implemented properly. Ihya As-Sunnah's community empowerment activities that have long been carried out by Ihya As-Sunnah can be studied through 3 visions, namely the da'wah education division, the economic and social division, and the recreation and sports division, through these various visions also Ihya As-Sunnah so that they can always provide good input, provide understanding that can be accepted in the community without being hurt.
\end{abstract}

Keywords: Extension; Implementation; Da'wah Institution 


\section{A. Pendahuluan}

Salah satu hal yang substansial dalam keberhasilan dakwah adalah bagusnya dalam hal tingkat pengelolaan. Dakwah yang berhasil tidak terlepas dari dari adanya pengelolaan yang baik oleh para da'i yang terlibat dalam dakwah. Dakwah yang tingkat pengelolaannya minim, membuat kegiatan dakwah menjadi monoton, sulit untuk maju, tidak terkelola dengan baik dan dalam tingkat pelaksanaanpun minim kegiatan. Kegiatan dakwah yang dianggap baik pengelolaannya berbanding lurus dengan jumlah SDM yang terlibat dalam kegiatan tersebut. Di Indonesia, lembaga dakwah terdiri dari NU, Muhammadiyah, Persis dan sebagainya. Lembaga-lembaga tersebut, membuktikan bahwa baiknya pengelolaan akan memberi dampak pengembangan yang signifikan terhadap lembaga tersebut.

Dalam suatu acara yang mengajak untuk kepada kebaikan tidak sekedar tertuju pada segi nasehat saja, tetapi juga dari segi pelaku dakwah (seorang yang mengajak kepada kebaikan) dan juga target dakwah (seseorang yang menjadi penerima ajakan). Selain daripada itu dakwah juga mempunyai metode beragam, artinya 
dakwah senantiasa dihadapkan pada dinamika keberagaman dalam diri masyarakat yang menjadi mad'u. Keberagaman tersebut tidak bisa disama ratakan dalam proses dakwah, melainkan dibutuhkan suatu metode yang beragam pula disesuaikan dengan kondisi mad'u agar dakwah berjalan dengan efektif.

Interaksi berperan penting dalam wawasan yang komprehensif kepada beberapa bagian untuk mengajak kepada sebuah kebaikan, pastinya dalam hal itu tidak akan sama, mulai dari suatu kegiatan, ataupun pencapaian yang pasti diraih. Kenyataan berdakwah Nabi SAW juga para teman sejawatnya, didalam keseluruhan gerakan, dalam pencapaian itu mereka memperlihatkan suatu penduduk termasuk penduduk dari berbagai aliran yang ada dikota Madinah, dimana ialah pemilihan dari penduduk Yastrib yang tidak berakal, ialah berwujud suatu pencapaian dalam mengajak kepada kebaikan didalam pemahaman yang menyeluruh. Dan tak semudah yang difikirkan, tetapi pencapaian dalam memperjuangkan tidaklah sebentar dan saat ini yang kita ketahui yaitu kegiatan menyeluruh atau Amaliyyah Al Idariyyah, dengan upaya menciptakan hal hal yang baik, yang untuk mengajak kepada kebaikan dengan memakai media yang sudah tersedia.

Belakangan ini terjadi suatu peristiwa dimana banyak umat muslim mendengarkan dakwah dari mana saja, menyebarluasnya kegiatan dalam berdakwah. Saat ini bias kita lihat bahwa kegiatan dalam berdakwah bias kita temui bukan dimasjid saja, tetapi ditempat-tempat yang tidah biasa kita temui seperti dalam media internet, tempat penginapan, dan juga pusat perkantoran.

Kejadian ini adalah hal yang paling membahagiakan juga hal yang akan dilaluin nanti bagi seorang pendakwah untuk selalu memberikan hal hal yang memicu semangat para pendegar menyampaikan suatu pengetahuan yang ia dapat dengan jelas dan teratur.

Dalam kegiatan berdakwahpun memerlukan pendukung untuk meningkatkan keberhasilan . disini bisa kita temuai bahwa adanya seorang pendakwah yang kita ketahui dari sifatnya dan juga pemahamannya yakni dalam dirinya ataupun diluarnya. Kemudian dalam menyampaikan sebuah ajakan harus sesuai 
dengan yang diperlukan oleh para pendengar. Apabila semua itu terkontrol dengan baik maka hal yang ingin ditujukan akan tercapai. ${ }^{1}$

Maka itu, jika kegiatan dalam berdakwah di mlai dengan apa yang sudah dipersiapkan sebelumnya, akan membuat masyarakat menjadi lebih terkesan dan mudah untuk di lakukan dikehidupan masyarakat. Dari sini seruan kebaikan tak dipandang upah hati namun diinterpretasikan didalam suatu usaha. Hal ini menjadikan pengontrolan didalam manajerial dalam berdakwah. Namun Efektif juga efisien dalam menggelar suatu dakwah suatu hal yang harus diuatamakan.

Kegiatan dalam berkawah bias dikatakan mencapai suatu keberhasilan bila dalam berdakwah memenuhi capaian yang diinginkan, untuk mencapai hal itu memerlukan hal hal yang biasa dilakukan. Hal yang paling pas jika seseorang melakukan kegiatan dalam berdakwah dalam suatu lembaga, dengan mengguanakan anjuran anjuran yang sudah dipersiapkan sebelumnya mkan akan tercipta suatu pandangan yang baik oleh masyarakat tersebut. Teruntuk dalam mengundang seorang da'i.

Kegiatan pelaksanaan berdakwah berlandaskan aturan yang sudah disiapkan. Dalam kegiatan berdakwah tertuju diruang lingkup suatu kelompok ataupun kalangan demi tercapainya tujuan pelaksanaan yang luar biasa.. Rencana dibawa dengan sisetem bagus dan penyelenggaraan agenda yang tepat, membuat kegiatan dalam berdakwah menjadi lebih sempurna, dan cita-cita yang diinginkan terlihat asli dan nyata, tentunya untuk menciptakan hal yang di rencanakan. ${ }^{2}$ Soliditas antara anggota dalam pengelolaan dakwah seperti ini merupakan pula ajaran dari suatu warga yang dirancang oleh warga untuk membina diri itu sendiri dengan berinteraksi di ruang lingkup sekitar. Dengan demikian hal yang melatarbelakangi pembelajaran warga yakni dari warga, oleh warga dan terkhusus warga.

${ }^{1}$ H. M. Yunan Yusuf, Manajemen Dakwah, (Jakarta: Kencana Prenada Media Group, cet. ke1, 2006), hlm. 79

${ }^{2}$ M. Munir dan Wahyu ilaihi, Manajemen Dakwah, (Jakarta: Kencana, 2006), hlm. 33 
Ihya As-Sunnah merupakan salah satu lembaga dakwah yang saat ini tengah mengalami perkembangan. Pada awalnya, Ihya As-Sunnah merupakan lembaga pendidikan pondok pesantren yang tersebar dibeberapa daerah di Indonesia. Namun, kini Ihya As-Sunnah berkembang menjadi lembaga dakwah yang berjuang memurnikan kembali ajaran Islam kepada masyarakat.

Ihya As-Sunnah dilihat dari ajaran dakwah yang dibawanya, sangat erat kaitannya dengan ajaran Salafi. Dalam studi literatur dijelaskan bahwa kelompok yang cerdas yakni kelompok Salafi, mereka tidak hanya ada di Negara Indosesia.namun mereka menyebar sampai ke daerah timur tengah. Kelompok ini berdiri dengan menempuh pembelajaran atau tempat belajar mengaji ${ }^{3}$

Mereka bekerjasama dengan Universitas yang berada di Timur Tegah dan juga yang ada di Negara Indonesia. Dimana kebanyakan dari mereka menjalankan kegiatan berdakwah diberbagai masjid. Contohnya Prof.Dr.Syakh Abdur Razzaq merupakan guru besar Universitas Jami'I Al-Islamiyah Madinah yang sering datang ke jakrta untuk memberikan tausiah. ${ }^{4}$

Kata yang biasa disebut Ustadz adalah panggilan yang biasa digunakan untuk memanggil ulama salaf itu sendiri. Pengembang dakwah salafi didaerah Mataram selama 9 tahun adalah Yazid bin Abdul Qadir Jawas. ${ }^{5}$

Selain daripada daerah-daerah di atas, Kota Bandung juga ada bentuk kegiatan dari Ihya As-Sunnah yang dikelola oleh Yayasan Tarbiyah Sunnah. Bersekretariat di Jl. Jurang Kecamatan Sukajadi di bawah kepemimpinan Abu Haidar. Karena ada beberapa lokasi yang dijadikan tempat kajian, maka kegiatan Ihya As-Sunnah di fokuskan di MBC.

Dalam studi pendahuluan di Majlis ta'lim Ihya' As Sunnah, berdasarkan hasil pantauan yang dilakukan pada kegiatan majelis selasa pagi di Masjid Cipaganti, terdapat suatu keunikan yang mencolok dalam kegiatan tersebut, khususnya mengenai pola pengelolaan Ihya As-Sunnah terhadap jamaahnya. Para

3 Imam Tholhah, Gerakan Islam Salafiyah di Indonesia. (Jurnal Edukasi Volume I Puslitbang Pemda Nomor 3 Juli-September 2003.

${ }^{4}$ Ibid.

5Ibid. 
jamaah yang hadir dalam kegiatan majelis tersebut menunjukkan suatu loyalitas yang cukup tinggi, selain daripada itu kohesifitas, konsistensi jamaah mengikuti kajian dan kefokusan jamaah selama mengikuti kajian menjadi poin plus bagi kegiatan Ihya As-Sunnah.

Antusiasme, loyalitas, kohesifitaas, konsistensi dan kefokusan jamaah Majlis ta'lim Ihya' As Sunnah dalam mengikuti kegiatan majlis menjadi hal yang sangat menarik untuk diteliti, untuk melihat bagaimana bentuk pengelolaan dakwah Majlis ta'lim Ihya' As Sunnah sehingga menjadi majelis yang cukup berkembang pesat dan senantiasa dihadiri oleh jamaahnya yang banyak. Maka, judul yang akan menjadi tema dalam penelitian ini adalah sebagai berikut: Pengelolaan Lembaga Dakwah (Studi Pengelolaan Program Dan Implementasi Lembaga Dakwah Majelis Ta'lim Ihya As-Sunnah di Kecamatan Sukajadi Kota Bandung Jawa Barat)

\section{B. Metode Penelitian}

Penelitian ini, penyusunannya menggunakan metode penelitian. Yang merupakan sebuah penelitian suatu kejadian atau kasus yakni dimana penelitian itu sendiri di jalankan secara mendalam kepada suatu kelompok organisasi, atau kejadian tertentu. dan selalu berhati-hati dalam melakukan penelitian tersebut. Jika kita melakukan sebuah penelitian dari area, maka penelitian itu hanya seputar area situ saja, dan memiliki jangkauan yang ridak cukup luas, akan tetapi dapat diteliti lebih mendalam. ${ }^{6}$

Studi kasus sendiri merupakan bagian dari penelitian kualitatif. Ketika kita meneliti menggunakan penelitian secara alamiah dengan memakai beberapa hal yang tersusun untuk melakukan penelitian disebuah kasus yang sedang terjadi atau belum terjadi. Mengapa alasannya kita menggunakan penelitian secara alamiah ini, sebab apa yang kita teliti nanti ditempat kejadian akan selalu berubah dengan rancangan kita, pasti aka

'Suharsimi Arikunto, Prosedur Penelitian Suatu Pendekatan Praktek Edisi Revisi V , (Jakarta: Rieneka Cipta, 2010), hal. 120. 
nada hal baru yang akan kita temui saat meneliti, dan juga apa yang akan kita teliti bisa berkembang samahalnya dengan saat kondisi ditempat kejadian berlangsung. Dan juga banyak sekali seorang peneliti yakin dengan penelitian secara alamiah ini karena akan memberikan hasil informas yang sangat menguntungkan .7

Maka dari itu mengapa seorang peneliti mau menggunakan penelitian ini, karena ingin mengetahui secara lebih dalam lagi seperti kasus yang terjadi ditempat kejadian tersebut. ${ }^{8}$ Rancangan pengkajian ini digunakan sebagaimana umumnya susunan kajian yang memakai penelitian alamiah dan bias any aini hanya bersifat sementara saja , tidak berlangsung lama dan sangat memperhatikan pembentukan teori. ${ }^{9}$

Meneliti sebuah kasus ialah media paling penting bagi peneliti dengan menyajikan sesuatu yang dilihatnya atau kasus yang didalami, maka dari itu ditemukan konsistensi dalam dan konsistensi baru terjadi namun juga keyakinan . ${ }^{10}$ Dipilihnyastudi suatu masalah sebagai susunan pengkajian untuk mempertahankan keaslian kasus pengkajian ini dapat bisa dijawab dengan kasus dalam masalah tersebut. Adalah agar bisa bagaimana pengelolaan lembaga dakwah Majelis Ta'lim Ihya As-Sunnah. Pendekatan penelitian yang dipakai dalam pengkajian tersebut berdasarkan kajian- kajian yang menjadi landasan dengan pengkajian ini yakni kasus tentang pengelolaan organisasi, budaya komunikasi dan teori komunikasi organisasi

Pengkajian yang biasanya dipakai yakni memakai pendekatan alamiah dimana pengkajian yang di sebutkan dalam

${ }^{7}$ Anselm Stauss, et.all; "Basic of Qualitative Research : Grounded Teory Prosedures and Techniques", diterjemahkan oleh Mohammad, Sodiq et.all. Dasar-dasar Penelitian Kualitatif: Tata Langkah dan Teknik-teknik Teorisasi Data (Yogyakarta: Pustaka Pelajar, 2003), hal. 5

8Imam Suprayogo, et. All., Metodologi Penelitian Sosial Agama (Bandung: Remaja Rosdakarya, 2003), hal. 9

9Sukidin, et. All., Metode Penelitian: Membimbing dan mengantar Kesuksesan Anda Dalam Dunia Penelitian (Surabaya: Insan Cendekia, 2005), hlm 23.

10Deddy Mulyana, Metodologi Penelitian Kualitatif., Paradigma Baru Ilmu Komunikasi dan Ilmu Sosial Lainnya (Bandung: PT. Remaja Rosdakarya, 2003) , h 201 
mengartikan kejadian mengenai yang diderita oleh orang tersebut. Dasar dijadikannya pengkajian alamiah dengan kasus ini yakni disebabkan dalam pengkajian ini lebih kepada pengamatan terhadap pengelolaan sebuah lembaga dakwah, diamana bentuk datanya yang lebih bersifat naratif. Contohnya kata kata masukan yang baik, tingkah laku, dan pandangan. ${ }^{11}$

\section{Hasil Penelitian}

1. Pengelolaan program pada Majelis Ta'lim Ihya AsSunnah.

\section{a. Rencana yang disusun Majlis Ta'lim Ihya As- Sunnah}

Agenda pelaksanaan kumpulan majlis Selasa pagi Ihya As-Sunnah dinyatakan oleh Agus Setiawan bahwa majelis ta'lim Selasa pagi ini merupakan programIhya AsSunnahyang awalnya dianggap pesimis, bisa berhasil karena hari kerja dan jam kerja. Namun berjalannya waktu menjadi sukses, karena jamaah semakin bertambah. ${ }^{12}$

Membahas tentang suatu agenda dimajlis sama halnya ketika disampaikan oleh Ustadz Agus Setiawan :13

"Perencanaan program ihya As-Sunnah disusun melalui rapat kerja yang dimulai setelah dibentuknya pengurus baru, melalui rapat kerja ini dirumuskan beberapa program kerja tidak hanya program kerja majelis ta'lim tetapi juga program kerjalhya AsSunnahsecara keseluruhan, penyusunannya pun hanya berdasarkan pendapat pengurus dan juga analisa dari pengurus tanpa melibatkan masyarakat/jama'ah."

Agus Setiawan ${ }^{14}$ menjelaskan bahwa program agenda yang di niatkan oleh majlis selalu mengacu pada

11 Lexy J. Moleong, Metode Penelitian kualitatif, (Bandung: Remaja Rosda Karya, 2008), hlm. 84

12 (Hasil wawancara dengan Agus Setiawan, selaku sekretaris umum Majelis Ta'lim Ihya As-Sunnah, 18 Juni 2017)

13 (Hasil wawancara dengan Ustadz Abu Umar, selaku Ketua umum Majelis Ta'lim Ihya As-Sunnah, 25 Juni 2017) 
pengurusnya saja tanpa mengikut sertakan masyaraka maupun tokoh disitu untuk ikut andil dalam perencanaan agenda. Akan tetapi setiap tahunnya program yang disampaikan sama persis dengan program-program ditahun sebelumnya atau meniru program terdahulu sama halnya yang diucapkan Ustadz Abu Umar "Kalo program majelis ta'lim Selasa pagi dari jaman saya hanya ikut - ikutan trussekarang jadi pengurus, ya sama saja, gitu-gitu saja programnya". Ketika membuat rencana dalam memilih mubaligh Ustadz Abu Umar mengucapkan : 15

"Untuk mubaliq yang rutin ada empat yang memiliki potensi yang relevan, dengan alasan bahwa diharapkan nanti mendapatkan informasi dan wawasan yang lebih luas, tidak hanya di sekitar sukajadi atau sekitarnya saja, tetapi kalo pas kebetulan mubaligh berhalangan hadir pengurus/pengelola sudah siap untuk mencari penggantinya, yaitu dari mubaligh cabang Ihya As-Sunnah lain"

Ketika saat belajar tidak ada kesulitan dikarenakan majlis ini hanya diadakan setiap hari Selasa pagi jadi warga sudah terbiasa dengan keadaan tersebut, apalagi khusus warga sukajadi dan warga disekitar pemungkiman daerah sukajadi, dalam merencanakan dana untuk majlis ini setiap hari Selasa memakai uang yang didapatkan dari sedekah para jamaah setiap kajian, dan para agniya jamaah biasanya akan mengumpulkan dari iuran untuk hal yang tiba-tiba datang, seperti menengok orang yang sedang sakit, ataupun agenda diluar jadwal, pengumpulan dana dijalankan di majlis maupun Ihya As-Sunnahsecara spesifik dana yang mereka dapatkan yakni dari pengumpulan uang sedekah di tiap agenda kajian,disampaikan oleh Ustadz Abu Umar ketika : "Perencanaan anggaran dilakukan pada saat

14 (Hasil wawancara dengan Agus Setiawan, selaku sekretaris umum Majelis Ta'lim Ihya As-Sunnah, 18 Juni 2017)

15 (Hasil wawancara dengan Ustadz Abu Umar, selaku Ketua umum Majelis Ta'lim Ihya As-Sunnah, 25 Juni 2017) 
pembuatan proposal program, tapi mencari dananya saat program mau berjalan saja".

Kemudian untuk agenda pembangunan Ustadz Abu Umar menjelaskan

"Perawatan dan pengadaan sarana prasarana menggunakan uang infaq parajama'ah tarkadang juga dari donatur masyarakat sekitar."

Ketika mempersiapkan jamaah agar mau menerima majelista'limIhya As-Sunnah Ustadz Abu Umar mengatakan bahwa : "Perencanaan dilakukan dengan meminta bantuan dari tokoh masyarakat dan tokoh agama yang ada di sukajadi untuk meyakinkan dan memotivasi masyarakat untuk berpartisipasi dalam berbagai kegiatan yang dilaksanakan majelis ta'lim Selasa pagi ini, karena masyarakat disini lebih mempercayai tokoh masyarakat dan agama." 16

Untuk perencanan penyusunan materi pembelajaran, pemilihan materi dan metode pembelajaran yang akan disampaikan setiap minggunya, Ustadz Abu Umar mengucapkan, "Hal ini dilakukan langsung oleh mubalignya, seperti juga yangdiungkapkan bahwa untuk perencanaan penyusunan materi, pemilihan danmetode pembelajaran ditangani oleh mubaliq",

Dari pandangan majlis ta'limIhya As-Sunnah bahwa suatu agenda yang dilakukan oleh Ihya AsSunnah memang hanya pengurus saja yang dilibatkan, jama'ah/masyarakatmengajukan usulan melalui WA, FB, Radio dan Internet yang sudah direncanakan dan diselengarakan olehlhya As-Sunnah, seperti yang dikatakan olehSiti Solihati (salah satu jamaah kegiatan Ihya As-Sunnah) bahwa: "ketika pengurus Uhya AsSunnah dalam rapat merencanakan program, dan merencakan segala hal kegiatan yang berhubungan denganIhya As-Sunnah, saya dan juga jama'ah kajian yang lainnya tidak pernah ikut, saya cumaterimaberes

16 (Hasil wawancara dengan Ustadz Abu Umar, selaku Ketua umum Majelis Ta'lim Ihya As-Sunnah, 25 Juni 2017) 
saja, tapiyang sayarasakan kegiatanmajelis ta'limIhya AsSunnahbermanfaat untuk saya dan jama' $a h^{\prime \prime 17}$

\section{b. Kegiatan Organisasi Majelis Ihya As-Sunnah}

Ketika organisasi dalam suatu agenda kegiatan Ustadz Abu Umar menyatakan dalam mengorganisasi program diserahkan langsung pada ketua majlis guna untuk mengorganisasi program ini, hal tersebut juga di ungkapkan oleh Agus Setiawan: "Untuk pengorganisasian program saya serahkan langsung semuanya ke ketua mejelis yang lebih tahukebutuhan apa yang diperlukan,"

Organisasi dalam program mubaligh dimajlis ta'lim Selasa ini hak penuh pembina untuk memilih Ustadz yang tepat dan sesuai. Berdasarkan hal tersebut Ustadz Abu Umar menyatakan bahwa :18

"PengelolaIhya As-Sunnahsudah mempunyai ketua dan tim tujuh serta pengurus di masing masing divisi seperti halnya majelis ta'lim Selasa pagi, dari pengurus majelis itulah pengelola meminta beberapa mubaliq dari beberapa daerah di luar sukajadi untuk mengisi pengajian setiap minggunya, atas referensi dari beberapa tokoh masyarakat seperti mubaliq setempat, agar lebih mudah."

Dan untuk agenda pembangunan Ustadz Abu Umar menyatakan halini juga langsung diserahkan kepada divisi rumah tangga, kemudian dirapatkan di musyawarah kerja tahunan, dikomunikasikan dengan divisi yang lain yang kemudian diajukan ke tim tujuh, dan dari tim tujuh diajukan ke ketua dan Pembina.

Untuk pengorganisasian anggaran program, Ustadz Abu Umar mengatakan bahwa : "Anggaran kegiatan diserahkan kepada divisi ekonomi, setelah berkomunikasi dengan divisi dakwah dan media, yang kemudian

17 (Hasil wawancara dengan Supriyadi, salah satu jamaah Majelis Ta'lim Ihya As-Sunnah, 2 Juli 2017)

18 (Hasil wawancara dengan Ustadz Abu Umar, selaku Ketua umum Majelis Ta'lim Ihya As-Sunnah, 25 Juni 2017) 
disusulkan ke tim tujuh, dan diajukan ke ketua dan pembina".

Sama halnya yang dijelaskan Ustadz Abu Umar : "Sejak awal bedirilhya As-Sunnahanggaran dana kegiatan diperoleh dari jamaah kajian, donatur yang belum bisa ikut kajian dan divisi usaha.Untuk kegiatan majelis ta'lim sendiri dananya diperoleh dari jamaah kajianyang kemudian dana tersebut di wujudkan dengan pemberian makanan ringan seperti membeli kertas, alat-alat kecil seperti bulpoint dan spidol itu diperoleh dari donatur masyarakat atau jamaah kajian."19

Dan juga pernyataan olehAgus Setiawan : "Iuran dari jama'ah dipegangoleh pengurus mejalis ta'lim yang di gunakan untuk kadangfoto copy beli bulpoint kertas, pokoknya untuk menunjang kegiatan mejelis ta'lim “ Ketika agenda saat belajar Agus Setiawan mengucapkan "SejakIhya As-Sunnahberdiri kegiatan ini hanya sabtu dan ahad saja rutin dilaksanakan, pas ada acara atau bertepatan dengan hari besar islam baru kegiatan ini libur, tapi diganti dengan pengajian yang cakupannya lebih luas seperti tabligh akbar, kajian tematik dan takhasus" 20

Ketika semua agenda dilaksanakan dimajlis ta'limIhya As-Sunnah yakni agenda yang terlibat hanya dari pembuat saja tanpa melibatkan warga sekitar.

\section{c. Latar Belakang Majelis Ta'lim Ihya As-Sunnah}

Dalam penggerakan/motivasi program ini disampaikan oleh Agus Setiawan bahwa dilakukan dalam rapat mingguan antar divisi, rapat bulanan yang dihadiri divisi, ketua dan pembina). "hasil rapat kemudian diserahkan kepada pengurus untuk sebagai bentuk pelayanan kepada jamaah, dan kemudian diberikan pula kepada UstadzUstadz yang akan memberikan materi yang dibutuhkan jamaah,

19 (Hasil wawancara dengan Ustadz Abu Umar, selaku Ketua umum Majelis Ta'lim Ihya As-Sunnah, 25 Juni 2017)

20 (Hasil wawancara dengan Agus Setiawan, selaku sekretaris umum Majelis Ta'lim Ihya As-Sunnah, 18 Juni 2017) 
adapun referensi kitab disesuaikan dengan kebutuhan masyarakat",dalam rangka membei muhasabah pada seorang mubaligh untuk mencapai peningkatan dalam menyampaikan materi yang telah diberi oleh pengelola.

Sama halnya dengan yang dikatakan Ustadz Abu Umar bahwa :21 "Ya kalo pengurus hanya menyerahkan sepenuhnya pada Ustadz untuk mengisi pengajian setiap selasa pagi dengan memberikan arahan materi apa saja dibutuhkan jamaah, digunakan materi tauhid, akhlak berbasis keilmuan. Pokoknya setiap jadwal yang sudah kita sepakati bersama ditepati, dan ketika sayaberhalangan hadir baru saya berkoordinasi dengan divisi dakwah hanya untuk memberitahukan bahwa saya tidak bisa hadir"

Kumpulan dalam majlis ta'limIhya As-Sunnahsadar apa yang sedang dikerjakan pengurus Ihya As-Sunnah untuk mempererat dan menjalin silaturahmi sesama muslim, dan juga mendorong masyarakat agar selalu menggelar acara rutin agenda dakwah islamiyah , makalhya As-Sunnah berusaha untuk tetap mempertahankan agenda rutin ini yang sudah dilaksanakan dari dulu, karena dikhawatirkan bisa berhenti secara tiba-tiba. Dalam hal ini di butuhkan kerjasama antara setiap muslim agar selalu menjaga kerukunan dan sealu ikut partisipasi dalam setiapp acara yang sedang di gelar atau diadakan oleh Ihya As-Sunnah, sama halnya yang disampaikan Nabila seoarang pengelola memberi masukan yang baik guna himbauan agar masyarakat ikut serta disetiap kumpulan dimajlis ta'limIhya As-Sunnah: "setiap awal pengajian ustadAgus Setiawan kadang juga Ustadz Abu Umar mesti memberitahu kepada semua jama'ah untuk diminta ikut kegiatanIhya As-Sunnahdan juga mengajak keluarga, relasi dan jamaah lainnya yang belum ikut untuk ikut bersama-sama dalam kegitan Ihya As-Sunnah".

\section{d. Bimbingan dalam Majelis Ta'lim Ihya As-Sunnah}

21 (Hasil wawancara dengan Ustadz Iskandar Dinata, selaku Mubaligh Majelis Ta'lim Ihya As-Sunnah, 2 Juli 2017) 
Suatu pembimbingan dalam kegiatan yang digelar dalam majlis ta'lim sama halnya dengan yang dikatakan Ustadz Abu Umar "hanya sekedar mengawal jalannya kegiatan saja, dan merawat supaya terus berjalan kegiatan Ihya As-Sunnah".

Ketua majelis ta'lim menegaskan Ustadz Iskandar Dinata: "apabila pembinaan untuk penggelola hanya terfokus pada bagaimana cara menyelenggarakan majelis ta'lim setiap minggunya, agar dapat berjalan secara berkelanjutan, melalui training keakraban seperti outbounddan jalan-jalan" 22

Suatu agenda pembangunan disampaikan Ustadz Abu Umar "Pembinaan dilakukan untuk memelihara dan mengoptimalkan sarana dan parsarana yang sudah ada agar bermanfaat dan optimal"

Ketua umum juga menyampaikan pembinaan dalam anggaran Ihya As-SunnahUstadz Abu Umar : "Pembinaan anggaranyadilakukan pada saat rapat kerja pas diawal kepengurusan, yaitu pembinaan pengoptimalan dana yang sudah diberikan dan bagaimana caranya supaya dapat dana tambahan,"

Untuk pembinaan ustad disampaikan oleh ketua majelis ta'lim Ustadz Iskandar Dinata: “Untuk pembinaan ustad hanya kita arahkan kepada pemberian materi sesuai dengan kebutuhan masyarakat, tapi bebas menurut sudut pandang nara sumber" Kemudian untuk membina warga yang sedang belajar seperti dikatakan olehUstadz Abu Umar "Pembinaan yang dilakukan hanya sekedar himbauan untuk mengikuti setiap kegiatan yangdilakukan oleh majelis ta'lim Ihya As-Sunnah" 23

Sama halnya dengan yang diucapkan oleh Ustadz Abu Umar bahwa "Pembinaan yang dilakukan oleh majelis ta'lim disampaikan setelah akhir kegiatan

22 (Hasil wawancara dengan Ustadz Abu Umar, selaku Ketua umum Majelis Ta'lim Ihya As-Sunnah, 25 Juni 2017)

23 (Hasil wawancara dengan Ustadz Iskandar Dinata, selaku Mubaligh Majelis Ta'lim Ihya As-Sunnah, 2 Juli 2017) 
pengajian yaitu hanya sekedar himbauan dan juga pengingat bahwa akan ada kegiatan saja."

\section{e. Pengontrolan Dalam Majlis Ihya As-Sunnah}

Dalam acara pengontrolan kegiatan ydalam majlis hanya dilaksanakan dalam setiap jumpa pengurus, sama dengan yang dikatakan Agus Setiawan :"kalo pengendalian kita hanya menyampaikan perkembangan majelis ta'lim, seberapa banyak antusias jama'ah untuk datang apakah meningkat atau menurun, tapi, ya tidak ada solusi kalo ternyata jama'ah yang datang dan mengikuti setiap kegiatan majelis berkurang, hanya wacana saja".

Bisa kita tau perbincangan tersebut jika sebuah pengendalian dilakukan hanya untuk melihat bagaimana adanya perkembangan tetapi tidak adanya jalan keluar, sama halnya dengan yang dikatakan Ustadz Abu Umar juga bahwa pengendalian penyelenggaraan majelis ta'lim: "Pengendalian penyelenggaraan majelis ta'lim hanya seperti yang dikatakan mas Agus Setiawan, selebihnya paling membahas tentang permasalahan - permasalah, terus bikin laporan tahunan nanti kalo pengurus sudah mau ganti periode"

\section{Pelaksanaan program kegiatan pada Majelis Ta'lim Ihya As-Sunnah.}

Jika di masa lampau sebuah majlis hanya sekedar berkumpul untuk memberi bekal pembelajaran yang biasanya dilakukan oleh sendiri-sendiri ataupun mencakup sebagai seorang kiyai, dan seorang ustadz. Namun saat ini perkemangan sebuah majlis menjadi suatu kelembagaan yang menjalankan pengajaran atau acara-acara islamiah dan dilindungi dalam naungan yang tinggi, baik dari perorangan, suatu kelompok, ataupun suatu organisasi.Dalam kegiatan awal acara yang dibuat majlis memiliki suatu tujuan yakni merangkul dan membina semua majlis yang ada disekitar daerah Sukajadi dalam suatu perkumpulan, jadi langkah dan tujuan dapat terarahkan. 
Mengenai Ihya As-Sunnah bisa katakana sebagai media dalam berinteraksi anatar sesama jamaan lainnya di Sukajadi. Ihya As-Sunnahterbagi menjadi majelis-majelis yangkemudian yang nanti akan membina suatu agenda yang sudah disiapkan dan telah dilaksanakan olehIhya As-Sunnah, ada beberapa agenda yang disampaikan dari awal priode kepengurusan 2008 hingga periode 2015-2016.

Dapat kita simpulakan bahwa pembinaan pada warga didaerah sukajadi melewati majelis ta'limIhya AsSunnahdapat dilihat dari agenda-agenda yang dijalankan oleh pengurus, adapun pembinaan kegiatan-kegiatan yang sudah dilaksanakan olehIhya As-Sunnah ada yakni dalam bersosialisasi dalam masyarakat, pembelajaran, jasmani dan rohani, dan juga keterampila: 
a) Divisi Pendidikan dan Dakwah

Dalam membina lewat pembinaan ini merupakan wadah untuk menciptakan karakter seseorang, dan juga mengetahui bagaimana tingkah laku seseorang tersebut. Ada juga agenda yang digelar As-Sunnah pada tahun 2008 hingga 2016 terlihat beberapa agenda yang sudah dijalankan dan juga dirasakan manfaatnya oleh warga 2014-2015terlihat juga bagaimana agenda yang sudah digelar oleh Ihya As-Sunnah berguna untuk warga Sukajadi. Sama halnya dengan yang disampaikan oleh salah satu orang majlis ta'limIhya AsSunnahSiti Solihatiseperti dikutip oleh peneliti:24 "dulu yang saya ingat pengajian-pengajian rutin yang saya ikuti, manfaatnyauntuk saya adalah, shalat yang dulu bolongbolong, allhamdulillah sekarang jadi rajin"

Hal tersebut juga dirasakan oleh Nurlela:25 "saya senantiasa mengikuti pengajian minggu pagi, alhamdulilahSaya sekarang sedikit-sedikit pamah tetang Agama, keutamaan sholat, terusmanfaat sholat duha, sholat tahajud, juga doa-doa keselamatan. Sekarang saya merasakan lebih tenang dan tenteram hati setelah mendengar ceramah-ceramah di majelis ta'lim Ihya As-Sunnah"

Melalui berbagai pengajian yang sudah dilaksanakan olehIhya As-Sunnah disatu acara pengajian Selasadigelar oleh pengelola dan yang nampat jelas ketika perubahan itu membawa hal-hal yang baik, dakwah yang dilaksanakan olehIhya As-Sunnah diharapkan dapat menjadi acuan masyarakat untuk berubah menjadi lebih baik oleh Nurul Hidayah seperti dikatakan: "Saya sangat terharu meskipun saya dikucilkan dari keluarga saya karena gara-gara saya pindah agama ke Islam, namun saya di assunnah mendapat ilmu luar biasa, untuk penguatan iman dan mental saya. Di assunnah, saya lihat temen-temen semuanya baik, bahkan saya dikasih kerudung buat menutup aurat, bahkan jamaah kajian yang dari Kopo menjahitkan baju gamis buat saya".

24 (Hasil wawancara dengan Supriyadi, salah satu jamaah Majelis Ta'lim Ihya As-Sunnah, 2 Juli 2017)

25 (Hasil wawancara dengan Yanti di, salah satu jamaah Majelis Ta'lim Ihya As-Sunnah, 2 Juli 2017) 
Kegitan dalam divisi pendidikan dan dakwah tahun 2008 hingga 2016 namun bukan saja pengajian yang yang berbasis tausiah saja yang diusahakan olehIhya AsSunnahuntuk meningkatkan strategi agama warga Sukajadi. Biasanya dalam upaya untuk meningkatkan kualitas afgama dimasyarakat diadakan seiap datangnya bulan suci ramadhan, agar dapatt menjadi media yang pas dalam peningkatan kualitas agama warga muslim sukajadi dengan menerapkan ajaran dalam beragama, seperti yang dikatakan oleh Ustadz Abu Umar yakni " kegiatan ramadhan explore antara lain pengajian akbar, buka bersama, lomba-lomba, kajian-kajian keagamaan" 26

Siti Solihati menerangkan jika peran Ihya As-Sunnah sangatmenguntukan untuk diri sendiri, peranIhya AsSunnahantara mengubah setiap tingkah laku masyarakat dan memberi wawasan yang cukup luas untuk warga Sukajadi. Bukan Cuma Siti Solihati yang dapat dirasakan manfaatlhya As-Sunnah, tetapiHanumjuga menuturkan bagaimanaIhya As-Sunnah banyaka sekali manfaat yang dapat dirasakan, seperti halnya yang dikataka peneliti:27 "Saya merasa kesulitan membaca Al-Quran, sekarang saya sedikit-sedikit mulai bisa membaca, walaupun Cuma membaca Al-Quran, Ihya AsSunnah setiap pengajiannya mengajari saya tentang ibadah yang benar menurut ajaran Islam. Ibu-ibu yang lain yang sering hadir juga merasakan hal yang sama, merasakan manfaat dengan mengikuti pengajian majelis ta'lim Ihya AsSunnah".

Dalam pembinaan keagamaan yang dilakukanlhya AsSunnahmelalui program-program,Ihya As-Sunnah masyarakat bisa menerima dengan baik dan mendapatkan penghargaan dari masyarakat sendiri. Karena dengan pengajian kita bisa saling bertegur sapa, bersilaturahmi dengan sesama muslim. Pada kenyataannya memang kegiatan yang dilakukakn saam berkumpul didalam majlis pengajia, menambah wawasan ilmu, menjadikan diri lebih dekat dengan Allah, dan bisa

26 (Hasil wawancara dengan Ustadz Abu Umar, selaku Ketua umum Majelis Ta'lim Ihya As-Sunnah, 25 Juni 2017)

27 (Hasil wawancara dengan Yanti di, salah satu jamaah Majelis Ta'lim Ihya As-Sunnah, 2 Juli 2017) 
memperbaiki akhlak seseorang, dan membentuk karakter warga sukajadi.

b) Divisi Ekonomi Bermasyarakat

Peran Ihya As-Sunnah selain dibidang beragama juga menyebarluar dalam bidang ekonomi dan kemasyarakatan. Dari aspek inilhya As-Sunnah berusaha guna merangkul rasa kebersamaan, indahnya bertoleransi, serta tidak menyusahkan orang lain. Masalah ini ditekankan dari majlis As-SunnahSiti Solihati: "Ihya As-Sunnahmengajak masyarakat terutama jama'ah pengajian untuk membantu pengajian akbar yang hampir setiap tahun diselenggarakan, kaloIhya AsSunnahpunya pekerjaan/punya kegiatan saya diminta ikut membantu jadi panitia, terusIhya As-Sunnahpernah mengadakan kegiatan lomba-lomba di waktu ramadhan".

Tidak hanya merangkul warga untuk ikut andil dalam tiap agenda yang digelar,Ihya As-Sunnahpada dalam setiap kegiatannya pengurus selalu membuat agenda yang membuat masyarakat Sukajadi bisa dengan mudah memiliki sikap bermasyarakat misalnya gotong royongi, pada tahun 20082009 hingga 2014-2015 agenda yang mengatur untuk bagian makanan pada acara majlis Selasa. Hal membuktikan bahwalhya As-Sunnahberusaha untuk memicu tumbuhnya rasa bermasyarakat pada majlis juga warga Sukajadi. Dalam agenda ini semoga bisa menumbuhkan rasa sikap toleransi, dan juga bertanggung jawab, namun tahun 2015-2016 agenda itu tidak diselenggarakan, Adajuga Acara SURGA (Silaturahim untuk Warga) dengan program ini semoga masyarakat bisa mempererat lagi tali silaturahmi antara jamaah yang hadir dengan pengelola sukajadi.t Sukajadi. Sama dengan yang diucapkan Siti Solihati: "saya senang mengikuti kegiatan SURGA, meskipun saya jarang berinteraksi dengan warga, namun dengan adanya kegiatan itu saya jadi tambah akrab dengan warga yang lain".

c) Aspek Pembelajaran

Beberapa aspek yang dilaksanakan ada salah satunya yang dijalankan oleh Ihya As-Sunnah didalam mencapai suatu harapan untuk mengasah kebolehan juga pandangan yang luas serta pembelajaran. Sebab dengan belajar bisa 
mengasah kemampuan seseorang untuk mencapai pendidikan yang baik .Ihya As-Sunnah juga merasakan bahwa pembelajaran yang diberikan kepada generasi muda sangatlah penting, sebab mereka yang akan hidup diasa yang aka dtang, dan menjadi bekal mereka di fase semua serba modern.

Ada salah satu peran Ihya As-Sunnah dalam hal untuk selalu mencontoh bagaimana zaman ini berkembang. Ditinjau dari continueIhya As-Sunnahjuga memperkenalkan suatu agenda untuk membangun warga dan juga generasi muda di sekitar sukajadi melewati agenda keagamaan da dimusyawarahkan dengan masalah yang sedang terjadi barubaru ini . Kegiatan yang pernah dilakukan oleh Ihya AsSunnah yakni yang merangkul agenerasi muda untuk memecahkan suatu permasalahan yang sedang terjadi atau sering menjadi perbincangan di sekitar warga. Masalah ini dijelaskan oleh Krishna Arya yang tidak lain satu pengurusIhya As-Sunnahbahwa:28 "saya sangat suka dengan forum remaja, walupun kegiatannya kadang ada kadang tidak tapi manfaat mengikuti kegiatan itu sangat terasa. Saya jadi tambah pengetahuan umum tentang agama dan juga dapat menyikapi masalah-masalah yang ada dimasyarakat dan masalah saya sendiri guna memperoleh pemecahan masalah".

Dibentuknya agenda yang merangkul kaum muda tersebut Ihya As-Sunnah kembali memperlihatkan bagaimana kepedulian atas warga sukajadi tak cuma orang tua namun generasi Ihya As-Sunnah selanjutnya berharap bahwa generasi muda bisa mencapai prestasinya. Ihya As-Sunnah. Selain itu Ihya As-Sunnah pada tahun 2012-2013 memiliki satu agenda yang disebut buletin hingga tahun 2014-2015 agenda tadi memperoleh penghargaan tersendiri dari masyarakat, dan juga para majlis yang hadir di sukajadi biasanya. Sebab dengan adanya media cetak yakni program bulletin target dakwah Thya As-Sunnah mendapatkan manfaat yang begitu luar biasa dan pengetahuan yang didapatkan cukup luas, selain itu Ihya As-Sunnah memberi peluang pada semua orang untuk berbagi ilmu yang bermanfaat dan disebarluaskan untuk hal hal yang baik melewati

28 (Hasil wawancara dengan Krishna Arya, selaku ketua Divisi Dakwah Majelis Ta'lim Ihya As-Sunnah, 8 Juli 2017) 
buletin.Namun tahun 2015-2016 Agenda bulletin belum terlaksana dengan baik, sebab keikut sertaaan dan dukungan masyarakat sudah tidak sama seperti dulu,mulai luntur.

Kegiatan yang berkecimpung diaspek keagamaan, maka Ihya As-Sunnah berusaha supaya semua yang telah dimulai dari nol tak berhenti dengan sia-sia. Cara menanggulangi masalah ini secara berkala Ihya As-Sunnah mengadakan memotivasi kembali yang bersifat membangun dan juga memberi pembelajaran pada warga Sukajadi, Tahun 2010-2011 dan tahun 2014-2016 Ihya As-Sunnah agenda tryout atau ulangan untuk muda mudi sekolah dasar, khususnya jika mereka mendekati saat akan melakukan Ujian Nasional guna membangun masyarakat agar memiliki peningkatan dalam belajar dan bisa mendorong pendidikan sama halnya dengan tujuan pendidikan nasional itu sendiri yakni, menanggulangi masyarakat dari kebodohan, dan meningkatkan kualitas pendidikan di Indonesia.

d) Dalam bidang Rekreasi dan olahraga

Ihya As-Sunnah berusaha menggunakan lat yang sudah tersedia, dimana seperti yang kita tau bahwa penyampaian dakwah tak hanya melalui tausiah dalam majlis secara langsung, namun bisa lewat rekreasi atau lewat kebugaran jasmani.

Jika kita menggunakan media rekreasi contohnya, sama halnya yang sudah Ihya As-Sunnah jalankan yakni setiap tahun akan ada agenda rekreasi, selain itu bisa membuat solidaritas juga kekeluargaa masyarakat Ihya As-Sunnah. Di dalam melaksankan dakwah muslim dan juga menjalin silaturahmi rasa persaudaraan baik disekitar area sukajadi ataupun sebagian warga muslim didaerah lain digunakanlhya As-Sunnah menggunakan media olahraga. Artinya tujuanIhya As-Sunnah dengan menggunakan media olahraga dan seni akan membuat orang menjadi sehat bugar baik jasmaninya ataupun rohaninya, sehingga ia mudah untuk menerima semua masukan yang sifatnya membangun diri demi kebaikan individu, maupun kelompok. Dan dibidang inilhya As-Sunnah mencoba menumbuhkan rasa toleransi yang tinggi disetiap agenda yang digelar oleh Ihya As-Sunnah 
diharapkan tercapainya dimana dalam masyarakat tersebut hidup rukun, aman, damai,dan sejahtera.

\section{Pengelolaan program pada Majelis Ta'lim Ihya As- Sunnah}

\section{a. Perencanaan}

Yang dimaksudkan perencanaan disini yakni dimana melakukan sebuah pagelaran dimana kita harus menyusun rancangan untuk dapat menuju harapan yang akan dicapai. Dan dalam agenda perencanaan yang dijalankan oleh majlis ta'lim Ihya As-Sunnah yang melewati suatu rapat kerja uyang dijalankan ketika awal tahun yang mengurus pengelolaan yang baru, dan yang merencanakan semua itu ialah Ihya As-Sunnah dan tidak melibatkan masayarakat ataupun oerangkat desa setempat. Sebab agenda yang direncanakan selalu tak pernah berubah, dan juga program yang direncanakan sama perish dengan kepengurusan yang mengelola sebelumnya.

Dan juga perencanaan yang membahas anggaran akan selalu dimusyawarahkan, sebab setiap kegiatan pastinya akan membuuhkan dana, baik itu dipakai untuk kepentingan majlis tau kepentingan mendadak, dan anggaran yang didapatkan yakni melalui berbagai sedekah para anggota pengajian ataupun orang yang memiliki usaha menyumbangkan dananya tanpa meminta timbal balik, dan tidak terikat kontrak.

Ketika ingin membuat perencanaan dalam sistem pembangunan yang diperbuat oleh pihak pengelola sendiri yakni memakai uang anggaran yang sebelumnya sudah diberikan kemudian juga mencari seorang donator untuk menyumbangka sebagian hartanya dalam membangun sarana dan prasarana.

Jika melakukan pembelajaran dalam majlis yang akan disampaikan dalam majlis tersebut pihak yang mengurus seketika memberikan materi kepada ustadz untuk digunakan saat dalam menyampaikan materi, dan memberikan pemahaman agar materi yang disampaikan oleh ustadz tersebut dapaat dipahami dengan baik. Akan 
tetapi program perencanaan dalam majlis t'lim belum terlaksana dengan baik, sebab saat menjalankannya tak mengikutsertakan masyarakat untuk menjadi sarana dalam membantu meningkatkan potensi yang dimiliki mayarakat agar dijaga dengan baik dan hasilnyapun bisa dinikmati bersama-sama.

\section{b. Pengorganisasian}

Organisasi yakni suatu kegiatan yang didalamnya terdapat suatu kegiatan yang dilakukan seseorang yang berkelompok. Dan kegitan yang dilakukan tidak sematamata hanya kegitatan,namun dalam kegiatan tersebut dijalankan untuk mencapai apa yang dituju.

Didalam majlis ta'lim Ihya As-Sunnah dibentuk suatu kegiatan organisasi untuk memudahkan seseorang dalam merancang kegiatan yang akan dijalankan, sehingga apa yang sudah direncanakan dapat berjalan sesuai rencana.

Saat melalukan perencanaan organisasi kegiatan, majlis ta'lim bekerjasama dengan pengelola hrian yakni Ihya As-Sunnah ketika menemakai keuangan diluar anggaran dana atau juga bisa melakukan iuran peranggota.

Kegiatan pembelajaran sendiri diamanahkan seutuhnya kepada seorang ustadz, namun materi yang disampaikan hanya tertuju pada satu pandangan saja, tidak menyampaikan pandangan atau pengetahuan yang lainnya. Jadi diharapkan agar kedepannya dapat menyampaikan materi dari berbai pandangan, sehingga ilmu yang didapat akan berkembang dan mendorong majlis ta'lim lebih maju.

\section{c. Penggerakan/Motivasi}

Motivasi yang dimaksudkan disini yakni suatu usaha yang dilakukan untuk menyemangati, mendorong seseorang atau anggota kelompok untuk mencapai suatu keinginan yang ingin dicapai. Sehingga apa yang dicapai dapat terlihat maksimal. Sama halnya dengan sebuah 
kegiatan, dalam kegiatan pasti akan selalu ada kendala, nah disini seseorang wajib memberikan motivasi untuk membangun rasa percaya diri anggota kelompok demi tercapainya suatu kegiatan yang direncanakan.

Hasil kajian dari pengelolaan majlis ta'lim aebagai tempat terbentuknya karakter atau perilaku seseorang belum dijalankan dengan baik dan belum memenuhi standar dalam pengelolaan suatu pendidikan tidak resmi yang diantaranya memiliki susuan : seorang pimpinan, sumber belaja yang memadai, seorang pelajar, program pembelajaran, media pembelajaran.

\section{d. Pembinaan}

Suatu pembinaaan bisa diartikan dimana keadaan seseorang yang dilatih untuk mencapai keadaan yang memang akan di jalani kedepannya. Dalam pengelolaan kegiatan pembelajaran juga harus mendapat binaan dari guru-guru, agar apa yang dijalankan dapat terealisasikan dengan baik. Dan pembinaan ini juga diterapkan dalam majlis seperti kegiatan yang akan dilaksanakan diluar ruangan dapat dijalankan sesuai yang diinginkan, tanpa suatu masalah atau kendala apapun.

Dalam pembinaan anggaran sarana dan juga prasarana hanya dilakukan pada saaat sedang rapat kerja diawal pengelolaan. Namun, pembinaan yang dilakukan oleh majlis ta'lim belum dijalankan secara sempurna, masih banyak yang harus ditingkatkan lagi, agar memenuhi standart pembelajaran pendidikan nasional.

\section{e. Pengendalian}

Yang dimaksud dalam pengendalian disini yakni mengawasi suatu kegiatan organisasi yang harus diselenggarakan sesuai dengan rancangan yang sudah dibuat sebelumnya, guna meminimalisir terjadinya hal yang fatal, sehingga dapat berjalan dengan lancer.

Kemudian pengendalian yang diterapkan oleh majlis ta'lim yakni dengan melihat lagi bagaimana acara yang berjalan pada sebelumnya, sehingga kesalahan atau ketidakpuasan dalam melakukan kegiatan tersebut bisa 
menjadi acan untuk kedepanya, sehingga dapat mengendalikan kegiatan dimasa yang akan dating dengan baik.

\section{Pelaksanaan program kegiatan pada Majelis Ta'lim Ihya As-Sunnah}

Dalam kegiatannya biasanya majlis ta'lim melalukan kegiatannya ditempat terbuka dan memiliki sifat terbuka, maksudnya siapa saja boleh bergabung tanpa mengenal usia, jabatan, dan juga jenis kelamin. Dalam kegiatannya pun acara yang dibuat tidak selalu dijam yang sama, bisa kapan saja, dan juga dimana saja. Kegiatan yang dilakukan biasanya dirumah, masjid, tempat rekreasi, lapangan, ataupun di gedunggedung. Lembaga dakwah juga masih eksis hingga saat ini, dakwah sendiri saat ini masih diterima denga baik oleh masyarakat luas, dan menjadi pendidikan yang sangat dekat dan bisa diterima dengan baik.

\section{Hasil Pelaksanaan Program Majelis Ta'lim Ihya As- Sunnah}

Berdasarkan hasil pembahasan di atas dapat digambarkan suatu perkembangan yang signifikan dari Majelis Ta'lim Ihya As-Sunnah. Berdasarkan hasil pengelolaan program yang dalam penelitian ini ditinjau mulai dari periode 2008 sampai dengan 2016, secara kuantitas jamaah serta kualitas lembaga mengalami kenaikan, walaupun di akhir periode mengalami penurunan.

Atas dasar kebutuhan adanya legalitas formal untuk memenuhi syarat perundang-undangan maka Majelis Ta'lim Ihya As-Sunnah kemudia bergabung dengan Tarbiyatul Aulad yang kemudian menjadi Yayasan Tarbiyah Sunnah. Setelah menjadi Yayasan Tarbiyah Sunnah, Yayasan mengalami perkembangan yang sangat cepat, dibantu dengan adanya media-media seperti Radio, Online, TV Streaming, dan Cetak, Yayasan Tarbiyah Sunnah berhasil menarik perhatian masyarakat bukan hanya masyarakat Sukajadi saja tapi sampai ke mancanegara.

Inilah bukti dari adanya loyalitas, kohesifitas, kefokusan dan rasa memiliki jamaah dan pengurus terhadap Majelis 
Ta'lim Ihya As-Sunnah. Tanpa adanya hal tersebut, Majelis Ta'lim Ihya As-Sunnah tidak mungkin dapat semaju saat ini. Dan berkat hal tersebut, keberjalanan program juga memberi dampak yang positif dan signifikan. Sehingga setelah menjadi Yayasan Tarbiyah Sunnah, penambahan jamaah dan efektifitas program dakwahnya semakin memperlihatkan kualitasnya.

\section{Kesimpulan}

Dari hasil pengkajian mengenai kepengurusan dalam majlis ta'lim sebagai tempat untuk membentuk karakter seseorang dan dari pendidikan sendiri menjadi acuan bagi warga sukajadi dalam mengamalkan setiap ajaran yang sudah diberikan. Toleransi terhadap majlis yang diadakan didaerah tersebut sangat dihormati dan juga diterima dengan baik. Dan tokoh Ihya As-Sunnah menjadi salah satu orang yang berpengaruh dalam aspek keagamaan serta kemasyarakatan di lingkungan sukajadi.

Dalam pengelolaan kepengurusan majlis ta'lim Ihya AsSunnah baru sampai tahapan rancangan, pengorganisasian kegiatan, pembinaan yang diberikan, dan juga pengawasan . Kemudian dalam pengorganisasian kegiatan belum dijalankan dengan semaksimal mungkin, karena dalam sebuah kegiatan organisasi haruslah adanya partisipasi masyarakat tersebut, jangan sampai berhenti ditengah jalan.

Motivasi yang dijalankan oleh pihak majelis hanyalah sebuah masukan, atau menghimbau terhadap para pengelola dan juga jamaah. Terkadang juga pengendalian yang dijalankan oleh pihak majlis belum terlaksana dengan baik.

Kegiatan pemberdayaan warga yang sudah lama dijalankan Ihya As-Sunnah bisa dikaji melewati 3 visi yakni divisi pendidikan dakwah, divisi ekonomi dan social, serta divisi rekreasi dan olahraga, melalui berbagai visi itu juga Ihya AsSunnah agar dapat selalu memberikan masukan yang baik, memberi pemahaman yang bisa diterima dimasyarakat tanpa adanya yang tersakiti. Dan yang menjadi patok utama dalam memberi pendidikan yang memiliki karakter yakni dengan berkata jujur, selalu tepat waktu, bertanggung jawab atas setiap yang dilakukan, saling menghargai, pekerja keras pantang 
menyerah, punya khayalan nyata yang tinggi, mandiri tidak lemah, bebas dalam mengutarakan pendapat, selalu tenang dalam keadaan apapun, peduli dengan sesama,baik itu makhluk hidup berupa tumbuhan atau manusia.

\section{Daftar Pustaka}

Yunan Yusuf, Manajemen Dakwah, (Jakarta: Kencana Prenada Media Group, cet. ke1, 2006),

M. Munir dan Wahyu ilaihi, Manajemen Dakwah, (Jakarta: Kencana, 2006)

Imam Tholhah, Gerakan Islam Salafiyah di Indonesia. (Jurnal Edukasi Volume I Puslitbang Pemda Nomor 3 JuliSeptember 2003.

Suharsimi Arikunto, Prosedur Penelitian Suatu Pendekatan Praktek Edisi Revisi V, (Jakarta: Rieneka Cipta, 2010)

Anselm Stauss, et.all; "Basic of Qualitative Research : Grounded Teory Prosedures and Techniques", diterjemahkan oleh Mohammad, Sodiq et.all. Dasar-dasar Penelitian Kualitatif: Tata Langkah dan Teknik-teknik Teorisasi Data (Yogyakarta: Pustaka Pelajar, 2003)

Imam Suprayogo, et. All., Metodologi Penelitian Sosial Agama (Bandung: Remaja Rosdakarya, 2003)

Sukidin, et. All., Metode Penelitian: Membimbing dan mengantar Kesuksesan Anda Dalam Dunia Penelitian (Surabaya: Insan Cendekia, 2005)

Deddy Mulyana, Metodologi Penelitian Kualitatif., Paradigma Baru Ilmu Komunikasi dan Ilmu Sosial Lainnya (Bandung: PT. Remaja Rosdakarya, 2003)

Lexy J. Moleong, Metode Penelitian kualitatif, (Bandung: Remaja Rosda Karya, 2008) 